\title{
Water Quality at Supply Source and Point of Use in the Kathmandu Valley
}

\author{
Salina SHRESTHA*, Sadhana S. MALLA*, Yoko AIHARA*, Naoki KONDO**, Kei \\ NISHIDA*** \\ *Interdisciplinary Graduate School of Medicine and Engineering, University of Yamanashi, \\ 4-3-11 Takeda, Kofu, Yamanashi 400-8511, Japan \\ **School of Public health, The University of Tokyo, 7-3-1 Hongo, Bunkyo-ku, Tokyo 113-0033, \\ Japan \\ ***International Research Centre for River Basin Environment, University of Yamanashi, 4-3-11 \\ Takeda, Kofu, Yamanashi 400-8511, Japan
}

\begin{abstract}
Water scarcity is a major issue in the Kathmandu Valley. Also, from a health perspective, it is important to evaluate the relationship between the quantity and quality of available water. In this study, we identified the water source used, and its availability and quality at the source and point of use. This was done by conducting a questionnaire survey and measuring the level of indicator bacteria and free residual chlorine in domestic water sampled at households. The results showed that most households used mixed water sources, with piped water being preferred for consumption. Nonparametric statistical tests showed that the total coliform was significantly high in source water with a longer supply interval and also high in stored water. In addition, but not of statistical significance, Escherichia coli was mostly detected in source water with a longer supply interval and also in stored water. In contrast, the proportion of samples with free residual chlorine was lower in water with a longer supply interval. Partial correlations showed that a longer cleaning interval of water storage vessels was associated with lower water availability and might lead to contamination of stored water. Therefore, safe storage of water should be promoted at the household level, and water supply services should be improved at the regional scale.
\end{abstract}

Key words: household, Kathmandu Valley, water sources

\section{INTRODUCTION}

Diarrhoeal diseases are the leading causes of morbidity and mortality in less-developed countries (Esrey et al., 1985; Curtis et al., 2000; WHO/UNICEF, 2009). In 2004, 1.5 million people died worldwide because of diarrhoea, $80 \%$ of whom were from sub-Saharan Africa and South Asia (WHO/UNICEF, 2009). The World Health Organization (WHO) estimates that the majority of diarrhoea cases could be reduced by providing basic water hygiene and sanitation (Younes and Bartram, 2001). A key strategy in tackling this problem is the installation of protected sources such as boreholes, standpipes and wells to provide better-quality water (Van Zijl, 1966). However, a significant proportion of the global population still collects, transports and stores its own water for drinking, cooking and personal and home hygiene (Kindhauser, 2003).

In Nepal, the incidence of diarrhoea among children under five increased from 378 per 1,000 in 2007 to 598 per 1,000 in 2009 (MoHP, 2008/2009; MoHP, 2009/2010). The risk of diarrhoea in the Kathmandu Valley remains high, with the possibility of an outbreak every year (MoHP, 2010). According to a report by the Asian Development Bank (ADB), the supply of improved piped water was available to $79 \%$ of the

Address correspondence to Kei Nishida, International Research Centre for River Basin Environment, University of Yamanashi, Email: nishida@yamanashi.ac.jp

Received January 13, 2013, Accepted March 14, 2013. 
population in that area in 2010 (ADB, 2010). However, the total volume of piped water supplied was only 95 million litres of water per day (MLD), whereas 320 MLD are needed to meet the needs of the increasing population of the Kathmandu Valley (KUKL, 2010/2011). To compensate for the deficit, people use alternative sources such as dug wells, tube wells, springs, stone spouts, rivers, tanker supply, rainwater and water jars to meet their water needs (Yoden, 2010). Although the ADB report shows a relatively high coverage rate for the improved water supply, which meets Millennium Development Goal 7 and Target 10 for improved water, the reliability of the supply has not been considered. In fact, most areas of the Kathmandu Valley have an interrupted and inadequate water supply, which results in severe water scarcity, forcing people to store water for long periods. This water scarcity might also affect the maintenance of proper hygiene in water management within households. Post-source contamination of water increases the risk of diarrheal diseases (Musa et al., 1999). Therefore, it is important to understand water use and the relationship of water availability and storage behaviour with the quality of water used by the valley people at the source and point of use. An assessment of water use, attitude and practice is important in planning water-related interventional strategies for the prevention of waterborne diseases. In this study, we first identified the priority of water sources used for different domestic purposes. Subsequently, we selected the water source that was most preferred for domestic purposes and consumption for a further analysis of water quality. We determined water quality at the source with respect to the water supply interval. Next, we evaluated changes in water quality from the source to point of use, and the relationship of these changes with household water management. Finally, the relationship between water availability and the cleaning interval of water storage vessels was evaluated.

\section{METHODS}

\section{Study area}

We targeted the Kathmandu Valley, which is located in the upper part of the Bagmati River Basin in central Nepal. The valley consists of three districts: Kathmandu, Bhaktapur and Lalitpur (Rana and Murray, 2007). The watershed has a total surface area of $665 \mathrm{~km}^{2}$ within $27^{\circ} 32^{\prime} 13^{\prime \prime}$ to $27^{\circ} 49^{\prime} 10^{\prime \prime} \mathrm{N}$ latitude and $85^{\circ} 11^{\prime} 31^{\prime \prime}$ to $85^{\circ} 31^{\prime} 38^{\prime \prime} \mathrm{E}$ longitude. The central part of the valley is $1,300-1,400 \mathrm{~m}$ above sea level (m.a.s.1.) with a gentle, flat landscape, and is surrounded by mountains with altitudes exceeding 2,000 m.a.s.1. (JICA, 1990).

\section{Data collection}

Water sampling

Thirty-eight samples of tap water were collected from different areas of the valley during September 2012. Of these, 19 samples were collected directly from the tap source and 19 were collected from similar types of opaque, covered storage vessels (minimally affected by light) in the households. The samples were collected in $100 \mathrm{~mL}$ sterile polythene bottles, which were rinsed properly before sample collection. The $\mathrm{pH}$, electric conductivity, free residual chlorine, and bacterial indicators were measured immediately after sample collection.

\section{Questionnaire survey}

Information on the water source used, per capita water availability, water supply service 
level and water management in the households was collected using a questionnaire. In addition, one person per household was interviewed during the survey when the water sample was collected. Variables related to water use included types of water sources used for different purposes and per capita consumption of water for different purposes. The types of water sources were identified by asking 'What water sources is your family using?'. The answers included either tap water or groundwater. The daily water consumption per capita (litre per capita per day: L/c/d) was calculated by adding the values for the daily amount of water consumed divided by the number of family members. The water supply service level was assessed as the water supply interval, which was assessed by asking 'How many days ago was water supplied via the tap for the last time?'. The answers were dichotomized as one day or two or longer than two days. Household water management was evaluated by the cleaning interval of water storage vessels and storage duration by asking 'When did you last clean the storage vessel?'. Storage duration was measured by asking 'When did you fill the storage vessel with water?'.

\section{Water quality analysis}

Basic physicochemical indices

The $\mathrm{pH}$ and electric conductivity were measured using a portable $\mathrm{pH}$ meter (HM-20P, TOA-DKK, Japan) and an EC meter (CM-21P, TOA-DKK, Japan), respectively.

\section{Microbial analysis}

Two bacterial indicators were measured: total coliform and E. coli. The most probable number (MPN) method (Colilert, IDEXX, USA) was used for measuring the bacterial counts, with the reagent/sample mixture being poured directly into a Quanti-Tray. After removing the bubbles filled inside the sample-filled Quanti-Tray, it was placed onto a Quanti-Tray/2000 rubber insert of a Quanti-Tray Sealer, with the well side of the Quanti-Tray facing downwards. After sealing, the tray was incubated. Large and small positive wells were counted, and MPN was determined by referring to the Quanti-Tray/2000 MPN table.

\section{Free residual chlorine}

Free residual chlorine was measured by the colourimetric method using a free residual chlorine test kit (ENPHO, Nepal). Three drops of reagent were added to a $5 \mathrm{~mL}$ water sample and the change in colour was matched with a colour chart that showed concentrations in the range of 0.2 to $1.0 \mathrm{mg} / \mathrm{L}$.

\section{Statistical analysis}

Fishers' exact test was used to determine the relationship between water quality parameters and water supply interval. McNemar's test was used to assess the relationship between source and stored water quality. We defined 'not detected' in the microbial analysis as less than $1 \mathrm{MPN} / 100 \mathrm{~mL}$ and that in the free residual chlorine as less than $0.2 \mathrm{mg} / \mathrm{L}$ for the statistical analyses. Spearman's correlation was used to find the relationship of cleaning interval and storage duration with the indicator bacteria. Similarly, a partial correlation was used to find the relationship of the indicator bacteria with cleaning interval and storage duration, further controlling the confounding effect of each. Likewise, we further used Spearman's correlation to assess the relationship between cleaning interval and per capita water availability. All statistical analyses were 
performed using SPSS version 20 (SPSS Inc., USA).

\section{RESULTS AND DISCUSSION}

\section{Types of water used for different purposes}

Along with the field survey data collected during this study, we considered data from a population representative survey conducted by the ADB (2010) from 2,282 households in the Kathmandu Valley to identify the water sources used for different purposes, in order to check the consistency of our data. Of the households we surveyed, $27 \%$ used piped water only, $9 \%$ used groundwater only and $64 \%$ used mixed sources for domestic purposes (drinking, cooking and other uses). The ADB data illustrated a similar pattern of results, with the highest proportion $(53 \%)$ of household using mixed sources, followed by piped water and groundwater (Fig. 1). Among the surveyed households using piped services, $64 \%$ used the water source for drinking, 68\% used it for cooking and $32 \%$ used it for other domestic purposes. Similarly, the ADB data showed that $71 \%$ of households used water for drinking, $75 \%$ for cooking and $60 \%$ used it for other domestic purposes (Fig. 2). In the same way, the field survey data showed that among households using groundwater, $9 \%$ used the source for drinking, 14\% for cooking and $64 \%$ for other domestic purposes. Similarly, the ADB data showed that $15 \%$ of households used groundwater for drinking, $21 \%$ for cooking and $56 \%$ for other purposes (Fig. 3).

Regarding the quantity of water used per capita, the average quantities of piped water and groundwater used for drinking were $2.04 \mathrm{~L} / \mathrm{c} / \mathrm{d}$ and $1.74 \mathrm{~L} / \mathrm{c} / \mathrm{d}$, respectively. In addition, the average quantities of piped water and groundwater used for cooking were $3.04 \mathrm{~L} / \mathrm{c} / \mathrm{d}$ and $0.29 \mathrm{~L} / \mathrm{c} / \mathrm{d}$, respectively (Fig. 4).

The main sources of domestic water in the Kathmandu Valley are piped water and groundwater. Most households use piped water preferentially, with groundwater being used as the main supplementary source to fulfil the unmet demand. Piped water is preferred for drinking and cooking, and the per capita consumption of piped water is higher than that of groundwater for these purposes. Groundwater is mostly used for domestic purposes other than consumption. The reason for this might be that people of the valley consider tap water to be the safest water source for their health.

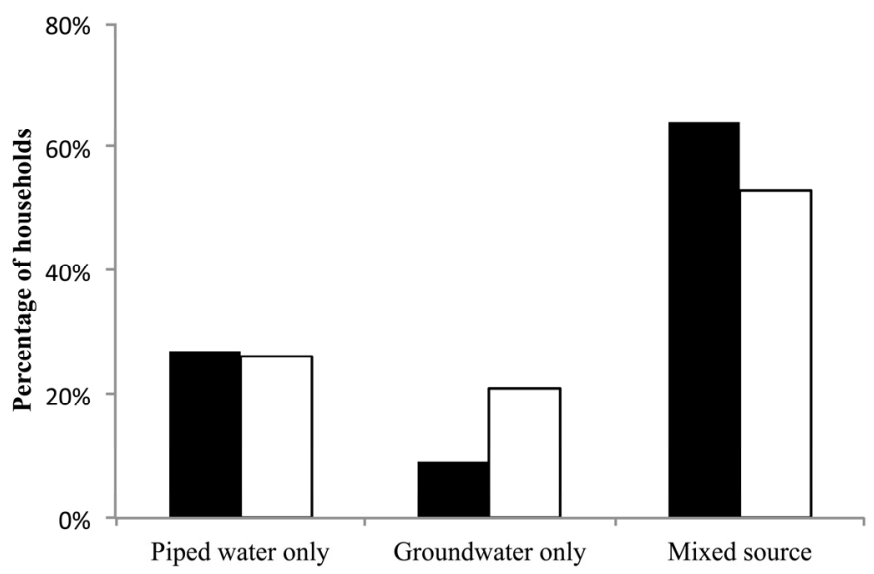

Fig. 1 - Proportion of households by types of water sources used. Black bars represent data from the present study and white bars represent data from ADB (Yoden, 2010). 


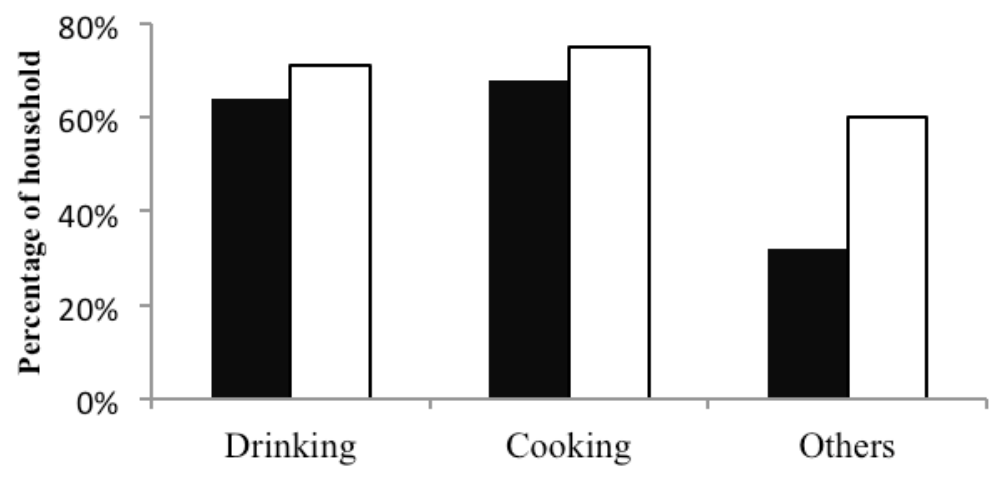

Fig. 2 - Proportion of households using piped water for different purposes. Black bars represent data from the present study and white bars represent data from ADB (Yoden, 2010).

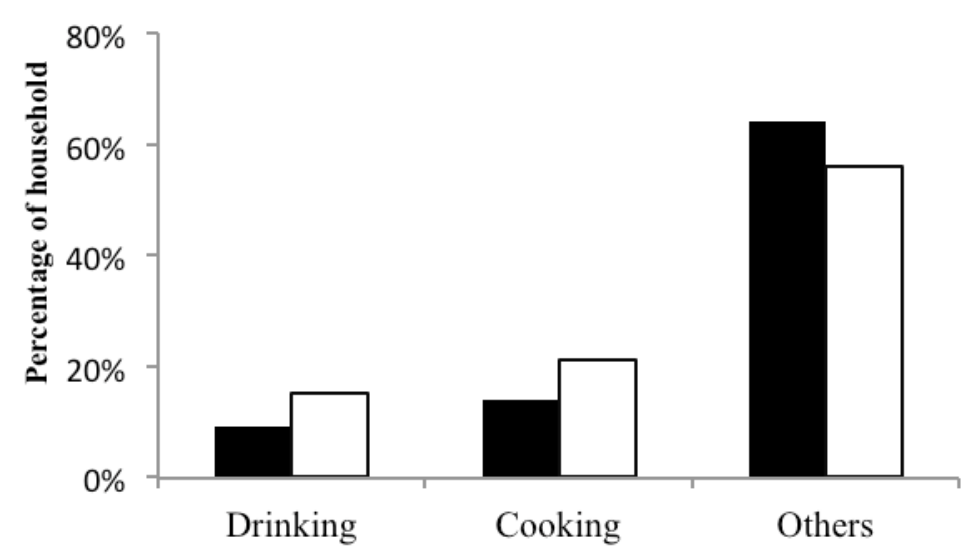

Fig. 3 - Proportion of households using groundwater for different purposes. Black bars represent data from the present study and white bars represent data from ADB (Yoden, 2010).

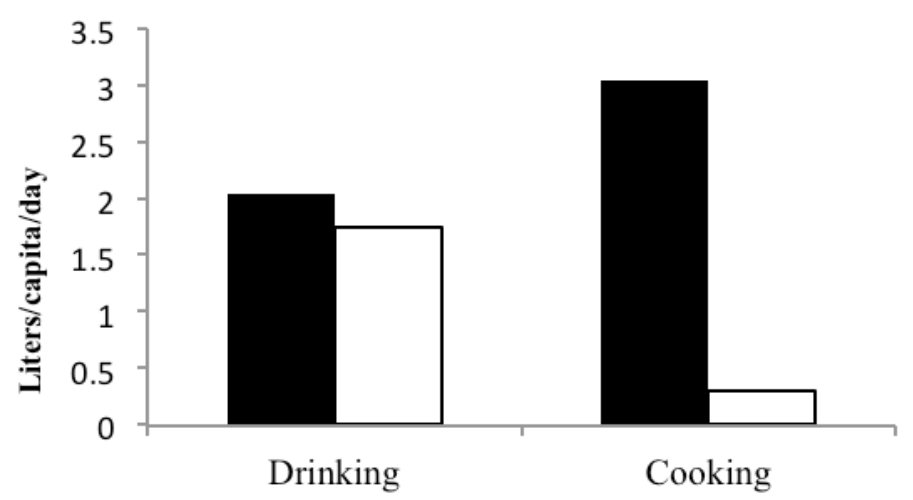

Fig. 4 - Amount of water consumed for different purposes. Black bars represent piped water and white bars represent groundwater. 


\section{General water quality}

The mean $\mathrm{pH}$ of collected water samples was 7.4 , with a range of 6.8 to 8.2. Similarly, the mean value for electric conductivity was 22 , with the range of 2 to $86(\mathrm{mS} / \mathrm{cm})$. Because the water samples were collected within a small area, it was assumed that the ambient temperature of stored water was similar among all locations.

\section{Water supply interval and water quality at the source}

Among the water samples collected from households with a water supply interval of one day, the total coliform was detected in $11 \%$ of samples, and the proportion of samples in which coliform was detected increased to $60 \%$ when the interval was increased to two or more days. The percentage of detection was significantly different $(\mathrm{p}<0.05)$ between the water supply intervals.

Similarly, E. coli was detected in $11 \%$ of samples in the case of a one-day supply interval, and this proportion increased to $50 \%$ with an increase in supply interval from two days to more than two days; however, these differences were not statistically significant (Table 1). The result of the water-quality analysis demonstrated that an increase in the water supply interval at the water source increased the chance of microbial contamination in the water. Water contamination in the distribution network is likely to occur because of the absorption of contaminants from the surroundings, resulting from cracks in pipes, and a lack of maintenance, resulting from the lower pressure within the pipes compared to the outer surface (Gadgil, 1998; Prasai et al., 2010). Consequently, the possibility of contamination increases with water supply interval because of the increased absorption of contaminants.

Free residual chlorine of $0.2 \mathrm{mg} / \mathrm{L}$, as recommended by WHO (WHO, 2008), was found in $44 \%$ of water samples with a one-day supply interval, whereas only $10 \%$ of water samples with a supply interval of two or more days showed $0.2 \mathrm{mg} / \mathrm{L}$ of free residual chlorine. This is because free residual chlorine dissipates in the distribution network and decreases with increasing levels of contamination (Power and Nagy, 1999). Although the water was chlorinated before distribution, the increase in contamination resulting from the lengthening of the supply interval causes rapid depletion of residual chlorine, further increasing the risk of contamination of the water (Ecura et al., 2011).

Table 1 - Relationship between piped water supply interval and water quality at the source.

\begin{tabular}{|c|c|c|c|c|c|c|c|c|}
\hline \multirow{2}{*}{\multicolumn{2}{|c|}{ Water Quality parameters }} & \multirow{2}{*}{\multicolumn{3}{|c|}{$\begin{array}{l}1 \text { day } \\
\mathrm{n}=9\end{array}$}} & \multirow{2}{*}{\multicolumn{3}{|c|}{$\begin{array}{c}\geq 2 \text { days } \\
n=10\end{array}$}} & \\
\hline & & & & & & & & P-value* \\
\hline \multirow{3}{*}{$\begin{array}{l}\text { Total } \\
\text { coliform }\end{array}$} & \multirow{2}{*}{$\begin{array}{c}\text { Conc. } \\
\text { (MPN/100 mL) }\end{array}$} & Mean & Min & Max & Mean & Min & Max & \\
\hline & & 14.6 & 10.7 & 22.7 & 445.6 & 297.5 & 774.1 & \\
\hline & Detection & & $1(11 \%)$ & & & $6(60 \%)$ & & $<0.05$ \\
\hline \multirow{3}{*}{ E. coli } & Conc. & Mean & Min & Max & Mean & Min & Max & \\
\hline & (MPN/100 mL) & 54.3 & 34.4 & 83.5 & 301.3 & 202.5 & 560.4 & \\
\hline & Detection & & $1(11 \%$ & & & $5(50 \%)$ & & 0.14 \\
\hline \multicolumn{2}{|c|}{$\begin{array}{c}\text { Free residual chlorine } \\
\text { detection }\end{array}$} & \multicolumn{3}{|c|}{$4(44 \%)$} & \multicolumn{3}{|c|}{$1(10 \%)$} & 0.14 \\
\hline
\end{tabular}

Note: *Fisher's exact test 
There were positive correlations between total coliform and E. coli concentrations in piped water $(\mathrm{r}=0.9)$ and stored water $(\mathrm{r}=0.7)$. Water samples in which free residual chlorine was detected had no microbial contamination. Therefore, the results of the statistical analyses using these three parameters were consistent with each other.

\section{Water quality at the source and point of use}

The percentages of piped water and stored water samples in which total coliform was detected were $37 \%$ and $74 \%$, respectively, which were significantly different $(\mathrm{p}<0.05)$. E. coli was identified in $32 \%$ of piped water samples and in $58 \%$ of samples of stored water; there was no significant difference in these values (Table 2). In addition, for both total coliform and E. coli concentrations, there was no positive correlation between piped and stored water. This study concluded that microbial contamination increased in water after storage. This finding is in line with that of a study conducted in Africa, which showed that water stored in a ground tank was more highly contaminated than water from a stand pipe (Maraj et al., 2009). Similarly, a study conducted in Sierra Leone revealed that although improved water met WHO guideline values at the source, the $E$. coli count increased incrementally over time to $244 / 100 \mathrm{~mL}$ in stored household water (Clasen and Bastable, 2003).

The ranges of cleaning interval and storage duration were $1-5$ and $1-7$ days, respectively. The increase in the total coliform in stored water was positively correlated with the cleaning interval of the storage vessel. Even after controlling for the effect of storage duration, there was significant positive correlation between the total coliform and cleaning interval $(\mathrm{r}=0.58)$. Likewise, after controlling the effect of cleaning interval, there was a weak positive correlation $(\mathrm{r}=0.34)$ between storage duration and increase in the total coliform (Table 3).

Table 2 - Relationship between water quality at piped source and storage.

\begin{tabular}{|c|c|c|c|c|c|c|c|c|}
\hline \multicolumn{2}{|c|}{ Water Quality parameters } & \multicolumn{3}{|c|}{ Piped water } & \multicolumn{3}{|c|}{ Stored water } & P-value* \\
\hline \multirow{2}{*}{$\begin{array}{c}\text { Total } \\
\text { coliform }\end{array}$} & $\begin{array}{c}\text { Conc. } \\
(\mathrm{MPN} / 100 \mathrm{~mL}) \\
\end{array}$ & $\begin{array}{l}\text { Mean } \\
244.1 \\
\end{array}$ & $\begin{array}{r}\text { Min } \\
161.7 \\
\end{array}$ & $\begin{array}{r}\operatorname{Max} \\
418.1 \\
\end{array}$ & $\begin{array}{c}\text { Mean } \\
511.2 \\
\end{array}$ & $\begin{array}{r}\text { Min } \\
324.9 \\
\end{array}$ & $\begin{array}{r}\operatorname{Max} \\
686.1 \\
\end{array}$ & \\
\hline & Detection & \multicolumn{3}{|c|}{$7(37 \%)$} & \multicolumn{3}{|c|}{$14(74 \%)$} & $<0.05$ \\
\hline \multirow[t]{2}{*}{ E. coli } & $\begin{array}{c}\text { Conc. } \\
(\mathrm{MPN} / 100 \mathrm{~mL}) \\
\end{array}$ & $\begin{array}{l}\text { Mean } \\
191.8 \\
\end{array}$ & $\begin{array}{r}\text { Min } \\
122.9 \\
\end{array}$ & $\begin{array}{r}\operatorname{Max} \\
334.5 \\
\end{array}$ & $\begin{array}{c}\text { Mean } \\
331.7 \\
\end{array}$ & $\begin{array}{r}\text { Min } \\
223.9 \\
\end{array}$ & $\begin{array}{r}\operatorname{Max} \\
609.5 \\
\end{array}$ & \\
\hline & Detection & \multicolumn{3}{|c|}{$6(32 \%)$} & \multicolumn{3}{|c|}{$11(58 \%)$} & 0.06 \\
\hline
\end{tabular}

Note: ${ }^{*}$ McNemar's test

Table 3 - Relationship between storage water quality and storage behaviour.

\begin{tabular}{ccccc}
\hline Storage behaviour & \multicolumn{2}{c}{ Total coliform } & \multicolumn{2}{c}{ E. coli } \\
\hline & Bivariate & Partial & Bivariate & Partial \\
& correlation & correlation & correlation & correlation \\
Cleaning interval & 0.45 & $0.58^{*}$ & 0.21 & $0.71^{* *}$ \\
Storage duration & 0.12 & 0.34 & 0.59 & -0.14 \\
\hline
\end{tabular}

Note: ${ }^{*} \mathrm{p}<0.05,{ }^{* *} \mathrm{p}<0.01$ 
There was a significant positive correlation between cleaning interval and $E$. coli after controlling for storage duration $(\mathrm{r}=0.71)$. In contrast, there was a weak negative correlation between E. coli and storage duration after controlling for cleaning interval, although this correlation was not statistically significant.

These results provide evidence of an independent positive association of the total coliform and E. coli with cleaning interval. The reason behind this might be that an increase in the cleaning interval negatively affects the hygiene of the storage vessel, which might result in the growth of microorganisms during storage, thereby increasing the risk of contamination of storage water. This result further illustrates that an increase in storage duration leads to an increase in the total coliform independently, whereas the risk of $E$. coli contamination increases with increased storage duration only in the case of a lack of hygiene of the storage vessel. In addition, mixing water that has been stored for a long time with freshly collected water affects water quality (Graham and VanDerslice, 2007).

\section{Water availability and sanitary behaviour}

An increase in the cleaning interval has a significant $(\mathrm{p}<0.05)$ negative correlation with per capita piped water availability (Table 4 ). The negative correlation between cleaning interval and per capita availability of piped water demonstrates that the less-frequent availability of water quantity affects hygiene practice (Tuttle and Ries, 1995). A lack of hygiene and environmental sanitation increases the risk of contamination, resulting in multiplication of microorganisms (Esrey et al., 1985). In addition, long-term water scarcity establishes a pattern of less-frequent water use behaviour, which negatively impacts long-term hygiene (Wutich, 2006).

\section{Strengths and limitations of the study}

The strengths of this study are that it documents the change in water quality from the source to point of use, as well as water management and behaviour of people in households in the Kathmandu Valley, which had not been well documented previously. Therefore, the study results are useful for their health implications. However, there are some limitations to this study. This is a cross-sectional study; thus, seasonal variations in water quality, water source used and quantity of water consumed cannot be identified. The sample size was relatively small and there was no statistical significance of $E$. coli detection in water samples. Thus, the study may lack statistical power.

Table 4 - Correlation between cleaning interval and water availability per capita.

\begin{tabular}{lcc}
\hline & $\begin{array}{c}\text { Total water } \\
\text { availability/capita }\end{array}$ & $\begin{array}{c}\text { Piped water } \\
\text { availability/capita }\end{array}$ \\
\hline Correlation coefficient & -0.27 & $-0.47^{*}$ \\
\hline Note: ${ }^{*} \mathrm{p}<0.05$. & &
\end{tabular}




\section{CONCLUSION}

The study is important in understanding the water sources used, water availability and the factors affecting water quality at the source and point of use, which will help in planning interventions to reduce waterborne diseases. We showed that water quality at the source is affected by an increase in water supply interval. Although the supplied water is treated before distribution, intermittent supply, cracks in pipes and lack of maintenance degrade the quality of the source water. An irregular and inadequate water supply compels people to store water for long periods, and microbial contamination was found to be higher in stored water than in source water. Moreover, the availability of water influences hygiene practices during storage, which further affects the quality of stored water. Most previous studies have focused on water quality at the source in terms of health benefits. However, our findings show that improving only water quality at the source does not provide assurance of safe water at the point of use, as quality often deteriorates after collection and storage. During this period, microbial contamination of water can increase, which reduces the health benefits of improving water quality at the source. Water quality at the point of use within a household is important along with the source water quality. Thus, at the household level, the appropriate intervention programmes for safe storage of household water should be promoted. At the regional scale, water supplies should be improved by providing sufficient and continuous service.

\section{ACKNOWLEDGEMENT}

We thank the Global Centers of Excellence (GCOE) program, University of Yamanashi, Japan, Grants-in-Aid for Scientific Research (No.70293438), and MEXT Scholarship Program for supporting the study.

\section{REFERENCES}

ADB (2010) Kathmandu Valley Water Supply and Waste Water System Improvement. Asian Development Bank, Kathmandu, Nepal. http://www2.adb.org/Documents/Reports/Consultant/NEP/34304/34304-01-nep-tacr .pdf.

Clasen T. F. and Bastable A. (2003) Faecal contamination of drinking water during collection and household storage: the need to extend protection to the point of use. $J$. Water Health, 1(3), 109-115.

Curtis V. S., Cairncross S. and Yonli R. (2000) Review: Domestic hygiene and diarrhoea - pinpointing the problem. Trop. Med. Int. Health, 5(1), 22-32.

Ecuru J., Okot-Okumu J. and Okurut T. O. (2011) Monitoring residual chlorine decay and coliform contamination in water distribution network of Kampala, Uganda. $J$. Appl. Sci. Environ. Manag., 15(1), 167-173.

Esrey S. A., Feachem R. G. and Hughes J. M. (1985) Interventions for the control of diarrhoeal diseases among young children: improving water supplies and excreta disposal facilities. Bull. World Health Organ., 63(4), 757-772.

Gadgil A. (1998) Drinking water in developing countries. Annu. Rev. Energ. Environ., 23(1), 253-286.

Graham J. and VanDerslice J. (2007) The effectiveness of large household water storage tanks for protecting the quality of drinking water. J. Water Health, 5(2), 307-313. 
JICA (1990) Groundwater Management project in Kathmandu valley, Final report. Japan International Cooperation Agency. Kathmandu, Nepal.

Kindhauser M. K. (2003) Communicable diseases 2002: global defence against the infectious disease threat. World Health Organization. http://apps.who.int/iris/bitstream/10665/42572/1/9241590297.pdf

KUKL (2010/2011) KUKL at a Glance, Third Anniversary. Kathmandu Upatyeka Khanepani Limited. Kathmandu, Nepal.

Maraj S., Rodda N., Jackson S., Buckley C. and Macleod N. (2006) Microbial deterioration of stored water for users supplied by stand-pipes and ground-tanks in a peri-urban community. Water $S A$, 32(5), 693-699.

MoHP (2008/2009) Annual Report. Department of Health Services, Ministry of Health and Population, Government of Nepal, Nepal.

MoHP (2009/2010) Annual Report. Department of Health Service, Ministry of Health and Population, Government of Nepal, Nepal.

MoHP (2010) Preparedness and Management of Diarrhea Outbreak 2010. DoHS. Epidemiology and Disease Control Division, Ministry of Health and Population, Nepal.

Musa H., Shears P., Kafi S. and Elsabag S. K. (1999) Water quality and public health in northern Sudan: a study of rural and peri - urban communities. J. Appl. Microbiol., 87(5), 676-682.

Power K. N. and Nagy L. A. (1999) Relationship between bacterial regrowth and some physical and chemical parameters within Sydney's drinking water distribution system. Water Research, 33(3), 741-750.

Prasai T., Lekhak B., Joshi D. R. and Baral M. P. (2010) Microbiological analysis of drinking water of Kathmandu valley. Scientific World, 5(5), 112-114.

Rana G. and Murray A. (2007) Kathmandu valley environment outlook. International Centre for Integrated Mountain Development (ICIMOD). Kathmandu, Nepal.

Tuttle J., Ries A. A., Chimba R. M., Perera C. U., Bean N. H. and Griffin P. M. (1995) Antimicrobial-resistant epidemic Shigella dysenteriae type 1 in Zambia: modes of transmission. J. Infect. Dis., 171(2), 371-375.

Van Zijl W. (1966) Studies on diarrhoeal diseases in seven countries by the WHO diarrhoeal diseases advisory team. Bull. World Health Organ., 35(2), 249-261.

WHO (2008) Guidelines for Drinking-Water Quality. World Health Organization, Geneva, Switzerland.

WHO/UNICEF (2009) Diarrhoea: Why children are still dying and what can be done. United Nations Children's Fund, World Health Organization, Geneva, Switzerland.

Wutich A. Y. (2006) The effects of urban water scarcity on sociability and reciprocity in Cochabamba, Bolivia. PhD thesis, University of Florida.

Yoden K. (2010) ADB TA 4893-NEP: Kathmandu Valley Water Distribution, Sewerage and Urban Development Project: PPIAF- supported Baseline Survey Part I, Asian Development Bank.

Younes M. and Bartram J. (2001) Waterborne health risks and the WHO perspective. Int. J. Hyg. Environ. Health, 204(4), 255-263. 